\title{
Tomato spotted wilt virus associated with lettuce dieback in Bekaa Valley, Lebanon
}

\author{
Elia Choueiri ${ }^{1}$ (1) $\cdot$ Fouad Jreijiri $^{1} \cdot$ Maria Saponari $^{2} \cdot$ Raied Abou Kubaa $^{2}$ \\ Received: 14 September 2020 / Accepted: 17 November 2020 / Published online: 25 November 2020 \\ (C) Società Italiana di Patologia Vegetale (S.I.Pa.V.) 2020 \\ Keywords Lactuca sativa $\cdot$ Lebanon $\cdot$ RT-PCR $\cdot$ TSWV
}

In August 2019, lettuce plants (Lactuca sativa) of Romaine hybrid showing virus-like symptoms such as brown necrotic spots, necrosis and drying out of one section of the lamina were observed in three fields located in Bekaa Valley (Bar Elias, Terbol and Zahlé areas) at various incidence (7\%, $10 \%$ and $15 \%$, respectively). Plants which became infected at an early stage grew poorly and often died. Samples from 32 symptomatic and 10 asymptomatic plants were collected from the three fields and were subjected to DAS-ELISA using commercially antibodies against alfalfa mosaic virus (AMV), tomato spotted wilt virus (TSWV), cucumber mosaic virus (CMV) and impatiens necrotic spot virus (INSV) (Loewe, Germany) (Clark and Adams 1977). All symptomatic plants reacted positively with the TSWV antiserum and no positive reaction was obtained from the asymptomatic plants. AMV, $\mathrm{CMV}$ and INSV were not detected. To confirm the occurrence of TSWV, primers L1 and L2 (Mumford et al. 1994) were used to amplify a $276 \mathrm{bp}$ fragment of the L RNA segment. PCR products of two positive samples (RAK-5.AS-1 and RAK-5.AS-4) were purified using PCR Purification Kit (Qiagen, USA) and sequenced in both directions. BLAST analysis of the sequences (GenBank accession numbers
LR878364 and LR878368) revealed $98.1 \%$ and $99.2 \%$ nucleotide identity, respectively, with TSWV isolate TRAntToMVEgp from Turkey (KC261947). TSWV was previously reported on tomato in the Byblos coastal area (AbouJawdah et al. 2006) but this is the first identification of TSWV on lettuce plants in Bekaa Valley.

\section{Compliance with ethical standards}

The authors declare that they have no conflict of interest from this research, and that it doesn't contain any studies with human participants or animals.

\section{References}

Abou-Jawdah Y, El Mohtar C, Sobh H (2006) First Report of Tomato spotted wilt virus on tomatoes in Lebanon. Plant Dis 90:378

Clark MF, Adams AN (1977) Characteristics of the microplate method of enzyme-linked immunosorbent assay for the detection of plant viruses. J Gen Virol 34:475-483

Mumford RA, Barker I, Wood KR (1994) The detection of Tomato spotted wilt virus using the polymerase chain reaction. J Virol Methods 46:303-311

Elia Choueiri

echoueiri@lari.gov.lb

1 Department of Plant Protection, Lebanese Agricultural Research Institute, Tal Amara, P.O. Box 287, Zahlé, Lebanon

2 CNR Istituto per la Protezione Sostenibile delle Piante, via Amendola 122/D, 70126 Bari, Italy 